\title{
Gene Action and Heterosis for growth and yield in bread wheat (triticum aestivum 1.)
}

Omar A. Ahmed Al-timimi ${ }^{1}$ - Department examination and certification of seeds, Iraq

Omarsumy1980@gmail.com .

Jassem M. Aziz aljubory² - Department of Agronomy, Faculty of Agriculture, Tikrit university, Iraq and . djasemfeahth@yahoo.com

A.A.A. EL-Hosary3 - Department of Agronomy, Faculty of Agriculture, Benha University, Egypt. a.elhosaryaa@yahoo.com

\begin{abstract}
Knowledge of type of gene action controlling target traits and genetic behavior is a basic principle for designing an appropriate breeding procedure for the purpose of genetic improvement. Hence, the success of any selection or hybridization breeding program for developing varieties depends on precise estimates of genetic variation components for traits of interest which may be additive, dominant and non-allelic interaction effects. Heterosis and nature of genetic effects on ealiness and yield traits were studied in a 10x10 diallel cross without reciprocals in wheat to define and select efficient and prospective material for immediate use in hybridization programs to improve grain yield of wheat in Iraq. Parents and $F_{1}$ were evaluated using (RCBD) with 3 replications for quantitative traits in (2017/2018) season. Significant genotype mean squares and its components (parents and crosses) were obtained for all traits in both generations. Significant heterosis in $\mathrm{F}_{1}$ generation was obtained for all studied traits. The useful heterosis of grain yield plant ${ }^{-1}$ relative to better parent varied from 12.46 to $36.82 \%$ in $\mathrm{F}_{1}$ crosses. The P7(Millan)xP8(Hithab) and P7(Millan)xP9(Ibaa 99) were the best crosses for grain yield heterosis. General (GCA) and specific (SCA) combining ability mean squares were significant for all traits. MS (GCA)/ MS (SCA) ratios indicated the relative importance of additive and additive by additive gene action in their inheritance for all the traits except for earliness and no. of spike plant ${ }^{-1}$. The three parents P1(Abu-Graib), P3(Osais), P5(Florka) and P9 (Ibaa 99) gave the highest positive significant $\hat{g}_{i}$ effects for grain yield plant ${ }^{-1}$ in the $F_{1}$ crosses. Twelve crosses showed significantly desirable heterotic effects for grain yield most studied traits.
\end{abstract}

Key words: Wheat, Diallel analysis, Gene action, combining ability.

\section{Introduction}

Wheat crop (Triticum aestivum L.) plays a major role in Iraq as well as for the majority of other countries. The Wheat crop is considered one of the most important strategic crops, which is often considered the main meal in the manufacture of many basic foodstuffs, So researchers are working on finding different ways to increase production per unit area, including breeding and hybridization methods through diversification of wheat breeding programs and development of a new range of high-yielding wheat varieties (EL-Hosary 2019b).

Heterosis is a complex phenomenon that depends on the balance of different combinations of genetic effects as well as on the distribution of excess and deficient alleles in the parents of the mating system. In self-pollinated crops, such as wheat, the scope of utilization of heterosis depends primarily on the direction and magnitude of the sclerosis. Better heterogeneity variance may be useful in determining the best crosses, but these hybrids can be of enormous practical value if they involve the best types of region (Prasad et al. 1998). The production of hybrid seeds for wheat is expensive and the economics of commercial production of hybrid wheat have not yet been prepared. The economic viability will be greatly improved if sufficient rigidity is maintained in the F2 generation to make the production value. Further progress in the production of this important species requires sufficient information regarding the nature of the parental pooling capacity available in a wide range of genetic material for use in the hybridization program as well as the nature of genetic activity to express features of its economic economic importance. According to Arunachalam (1976), Baker (1978), Ismail (2002), Joshi et al. (2004), Hassanein et al. (2006) and Farook et al. (2010), the ability to combine is a more reliable biometric tool to circumvent plant breeding programs. Diallel analysis also provides a unique opportunity to test a number of lins in all possible combinations. The aim of this study is to estimate the variability and ability to c.ombine in the first generation resulting from a group of dialect pairs for some quantitative traits of wheat crop.

\section{Materials and Methods}

Ten bread Wheat plant representing a wide range of variation were used $i$ the study the code number, names and percentages of the genotypes are shown in Table 1. 
Table 1. The code number, name and pedigree of the studied parental bread wheat varieties and lines.

\begin{tabular}{ccc}
\hline Code & Name & Pedigree \\
\hline P1 & Abu-Graib & Ajeeba* Lian $12 *$ Mexico 24 \\
\hline P2 & Kawz & Kauz $2 \backslash$ yaco $\backslash \backslash$ Kauz $\backslash 3 \backslash$ Ousis \\
\hline P3 & Osais & Ousis $\backslash$ Kauz $\backslash 4$ BUC \\
\hline P4 & Site mall & El-Solimania research center \\
\hline P5 & Florka & El-Solimania research center \\
\hline P6 & Kalak & El-Solimania research center \\
\hline P7 & Millan & El-Solimania research center \\
\hline P8 & Hithab & El-Solimania research center \\
\hline P9 & Ibaa 99 & Ures $\backslash$ Rows $\backslash 3 \backslash$ Jup $\backslash$ B $\backslash S \backslash$ Ures \\
\hline P10 & Sham 6 & Plo - Ruft GTOS - RHel (M12904) - IM - SM $-14-$ OSK - GAP
\end{tabular}

All possible combinations except for the exchanger were crossed during the growing season (2016/2017), giving the seeds (45) F1 crosses. Hybridization was carried out at the Agricultural and Experimental Research Station of Diyala Governorate. On September (15-2017), the trial included parents and conducted the first generation (F1) hybrid in (RCBD) design with three replicates at the Agricultural and Experimental Research Station in Diyala province. The replica consists of (55) rows representing parents and the length of F1 two meters long and (60) $\mathrm{cm}$ wide, and the plants inside the row (12) $\mathrm{cm}$ from each other. Recommended agricultural practices for the production of wheat were applied, including field operations such as agricultural fertilizers. Data were taken based on (10) randomly selecte plants from each piecplote. The following attributes were measured: days to headig, number of plant spikes ${ }^{-1}$, number of spike grains ${ }^{-1}$, number of spike grains ${ }^{-1}$, weight of 1000 grains, grain plant -1 . Relative heterosis was calculated for the middle of the parente according to Bhatt (1971) as a deviation from the first generation means performance from the better parental mean value. Estimates of geeral ad spcific combiing ability were determined according to Griffing (1956) for Method 2 Model 1.

\section{Results and Discussion}

Analysis of variance of $F_{1}$ generation for all studied characters is shown in Table (2). Genotypes, parents, crosses and parent $v s$ crosses mean squares were significant for all traits in $F_{1}$ generation, indicating the presence of diversity in the material and sufficient amount of genetic variability adequate for further biometrical assessment. Significant differences among genotypes for grain yield and related traits in different sets of material of wheat were reported by Joshi et al (2004), Seleem and Koumber (2011) and EL Saadoown (2018).

Table 2. Significance of mean squares from ordinary and combining ability analysis for all characters studied in $\mathrm{F}_{1}$ generation.

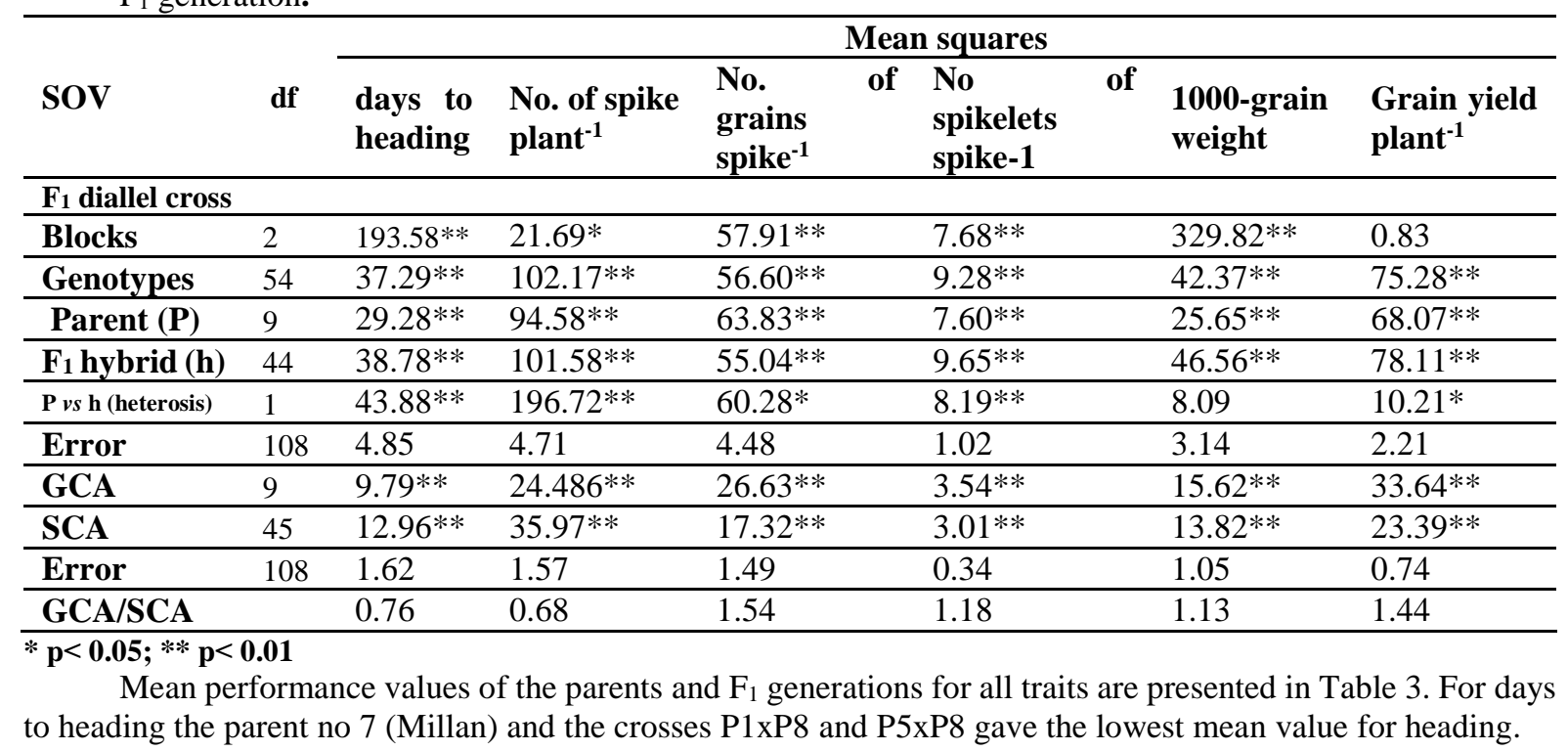


Table 3. Mean performance of all studied genotypes (parents and $F_{1}$ generation) for all studied traits.

\begin{tabular}{|c|c|c|c|c|c|c|}
\hline \multirow{2}{*}{ Genotype } & \multirow{2}{*}{$\begin{array}{l}\text { days to heading } \\
\text { day }\end{array}$} & \multirow{2}{*}{$\begin{array}{l}\text { No. of spikes } \\
\text { plant }^{-1} \\
\end{array}$} & \multirow{2}{*}{\begin{tabular}{|l} 
No of spikelets \\
spike-1 \\
\end{tabular}} & \multirow{2}{*}{$\begin{array}{l}\text { No of kernel } \\
\text { spike-1 }\end{array}$} & \multirow{2}{*}{$\begin{array}{l}\text { 1000-grain } \\
\text { weight }(\mathrm{g}) \\
\end{array}$} & \multirow{2}{*}{$\begin{array}{l}\text { Grain yield } \\
\text { plant }^{-1}(\mathrm{~g})\end{array}$} \\
\hline & & & & & & \\
\hline \multicolumn{7}{|l|}{ Parents } \\
\hline Abu-Graib (P1) & 99.67 & 19.77 & 21.87 & 43.21 & 37.03 & 45.59 \\
\hline Kawz(P2) & 107.00 & 20.44 & 20.13 & 59.78 & 38.00 & 38.88 \\
\hline Osais (P3) & 105.67 & 28.66 & 23.20 & 49.73 & 35.80 & 42.92 \\
\hline Site mall(P4) & 101.33 & 24.55 & 23.20 & 47.00 & 44.50 & 41.06 \\
\hline lorka(P5) & 106.67 & 23.44 & 22.53 & 51.69 & 36.70 & 48.41 \\
\hline Kalak (P6) & 103.00 & 25.44 & 22.80 & 45.00 & 36.33 & 37.26 \\
\hline Millan(P7) & 97.33 & 28.22 & 22.20 & 50.12 & 34.17 & 31.11 \\
\hline Hithab(P8) & 101.33 & 31.55 & 23.27 & 51.67 & 39.73 & 37.82 \\
\hline Ibaa 99(P9) & 102.00 & 37.77 & 26.27 & 47.02 & 37.17 & 41.53 \\
\hline Sham 6 (P10) & 104.33 & 32.17 & 21.40 & 51.51 & 40.47 & 39.05 \\
\hline \multicolumn{7}{|l|}{$\mathrm{F}_{1}$ crosses } \\
\hline P1xP2 & 99.00 & 24.33 & 20.07 & 49.02 & 35.10 & 44.46 \\
\hline P1xP3 & 100.33 & 15.44 & 22.73 & 41.89 & 37.53 & 34.93 \\
\hline P1xP4 & 101.00 & 23.33 & 21.47 & 44.01 & 31.00 & 46.93 \\
\hline P1xP5 & 98.33 & 25.88 & 22.40 & 46.12 & 38.80 & 37.43 \\
\hline P1xP6 & 107.00 & 28.44 & 21.47 & 51.79 & 40.37 & 41.52 \\
\hline P1xP7 & 105.67 & 17.44 & 22.47 & 44.10 & 31.67 & 36.42 \\
\hline P1xP8 & 96.33 & 25.22 & 21.80 & 47.67 & 40.50 & 47.92 \\
\hline P1xP9 & 107.00 & 24.89 & 21.27 & 45.57 & 34.90 & 37.43 \\
\hline P1xP10 & 105.67 & 22.77 & 30.27 & 47.87 & 36.80 & 41.06 \\
\hline $\mathrm{P} 2 \mathrm{xP} 3$ & 102.33 & 31.22 & 19.13 & 46.34 & 37.07 & 38.87 \\
\hline $\mathrm{P} 2 \mathrm{xP} 4$ & 101.67 & 28.55 & 22.60 & 47.88 & 41.20 & 44.91 \\
\hline $\mathrm{P} 2 \mathrm{xP5}$ & 109.00 & 27.66 & 22.13 & 49.88 & 43.00 & 35.82 \\
\hline P2xP6 & 105.00 & 30.13 & 20.87 & 44.30 & 44.90 & 42.81 \\
\hline $\mathrm{P} 2 \mathrm{xP7}$ & 107.00 & 21.89 & 21.93 & 48.89 & 38.80 & 42.53 \\
\hline $\mathrm{P} 2 \mathrm{xP} 8$ & 100.33 & 23.55 & 22.13 & 47.33 & 40.60 & 39.90 \\
\hline P2xP9 & 106.67 & 17.55 & 22.07 & 50.65 & 38.73 & 48.08 \\
\hline P2xP10 & 105.67 & 22.62 & 17.97 & 53.39 & 38.57 & 38.54 \\
\hline $\mathrm{P} 3 \times \mathrm{P} 4$ & 102.67 & 33.33 & 23.33 & 57.77 & 31.13 & 36.50 \\
\hline $\mathrm{P} 3 \mathrm{xP5}$ & 106.67 & 35.88 & 21.07 & 52.13 & 44.77 & 39.44 \\
\hline P3xP6 & 107.00 & 25.11 & 23.33 & 42.33 & 36.93 & 42.21 \\
\hline P3xP7 & 102.67 & 21.11 & 22.60 & 48.45 & 38.90 & 42.60 \\
\hline P3xP8 & 101.67 & 17.55 & 21.20 & 41.65 & 40.57 & 47.03 \\
\hline P3xP9 & 106.67 & 29.44 & 22.47 & 52.33 & 33.43 & 48.03 \\
\hline P3xP10 & 104.00 & 27.55 & 24.67 & 50.44 & 44.77 & 40.18 \\
\hline $\mathrm{P} 4 \mathrm{xP5}$ & 105.00 & 13.00 & 23.07 & 51.87 & 39.47 & 41.67 \\
\hline P4xP6 & 105.00 & 17.55 & 22.60 & 46.65 & 36.50 & 34.02 \\
\hline $\mathrm{P} 4 \times \mathrm{P} 7$ & 110.00 & 40.99 & 21.47 & 46.59 & 32.53 & 27.49 \\
\hline $\mathrm{P} 4 \mathrm{xP} 8$ & 113.00 & 22.78 & 24.07 & 55.55 & 31.20 & 30.37 \\
\hline $\mathrm{P} 4 \times \mathrm{x} 9$ & 105.67 & 27.66 & 21.60 & 52.55 & 41.83 & 44.45 \\
\hline P4xP10 & 101.67 & 19.00 & 21.20 & 50.58 & 37.57 & 35.95 \\
\hline P5xP6 & 98.33 & 17.55 & 19.20 & 46.20 & 39.83 & 42.74 \\
\hline P5xP7 & 105.67 & 26.11 & 22.20 & 55.78 & 30.93 & 40.75 \\
\hline P5xP8 & 97.67 & 26.77 & 20.67 & 41.53 & 38.07 & 45.53 \\
\hline P5xP9 & 99.00 & 19.77 & 20.93 & 48.87 & 40.23 & 39.95 \\
\hline P5xP10 & 107.00 & 26.11 & 21.07 & 50.01 & 40.17 & 45.34 \\
\hline P6xP7 & 103.00 & 21.89 & 23.07 & 50.22 & 39.30 & 34.11 \\
\hline P6xP8 & 107.00 & 20.33 & 22.80 & 47.61 & 36.07 & 44.16 \\
\hline P6xP9 & 106.33 & 36.00 & 22.60 & 45.01 & 31.70 & 50.37 \\
\hline P6xP10 & 105.67 & 20.00 & 21.47 & 42.75 & 31.83 & 46.06 \\
\hline P7xP8 & 104.33 & 18.11 & 24.07 & 50.09 & 32.70 & 47.15 \\
\hline P7xP9 & 108.67 & 27.77 & 22.93 & 53.57 & 40.03 & 45.18 \\
\hline
\end{tabular}




\begin{tabular}{lllllll}
\hline P7xP10 & 100.33 & 22.77 & 20.73 & 44.75 & 31.93 & 34.10 \\
\hline P8xP9 & 106.67 & 19.22 & 22.93 & 42.43 & 36.63 & 42.04 \\
\hline P8xP10 & 101.67 & 22.33 & 22.07 & 38.12 & 39.00 & 34.88 \\
\hline P9xP10 & 106.67 & 30.11 & 22.73 & 52.21 & 36.13 & 43.44 \\
\hline LSD 5\% & 1.06 & 1.03 & 0.97 & 0.22 & 0.68 & 0.48 \\
\hline
\end{tabular}

The parent no 9 (Ibaa 99) and the cross P4xP7 had the highest number of spikes plant ${ }^{-1}$. For No. of grains spike $^{-1}$; the P9 (Ibaa 99) and the three $F_{1}$ hybrid $\mathrm{P} 1 \mathrm{xP} 10$, expressed the highest values for this trait. The parent no 4 (Site mall) and $\mathrm{F}_{1}$ hybrids P2xP6, $\mathrm{P} 3 \mathrm{xP} 5$ and $\mathrm{P} 3 \mathrm{xP} 10$ was the highest hybrid for No of spikelets spike-1. For no of kernels spike $^{-1}$, the highest no of kernels were found by the parent no 2 (Kawz) and the cross P3xP4. As for 1000-grain weight, the parent no 4 (Site mall) and $F_{1}$ hybrids $\mathrm{P} 2 \mathrm{xP} 5, \mathrm{P} 2 \mathrm{xP} 6, \mathrm{P} 3 \mathrm{xP} 5$ and $\mathrm{P} 3 \mathrm{xP} 10$ were the highest hybrid for No of spikelets spike ${ }^{-1}$. Regarding, grain yield plant ${ }^{-1}$, P5 (Florka) and the cross combination P6xP9 expressed the highest value for this trait. On the other hand, the high grain yield plant $^{-1}$ was detected also, by the crosses $\mathrm{P} 2 \times \mathrm{P} 9, \mathrm{P} 6 \mathrm{xP} 9$ and $\mathrm{P} 3 \times \mathrm{P} 9$ whic could be attributed to the high values of No. of spikes plant, No. of grains spike ${ }^{-1}$ and grain yield plant ${ }^{-1}$. Therefore, these crosses could be efficient for prospective wheat breeding programs aiming at improving wheat grain yield.

\section{Heterosis}

Mean squares for parents $v s$ crosses in $\mathrm{F}_{1}$ generation, as an indication of average of heterosis in
$F_{1}$ across all crosses were significant for all the studied traits (Table 2). The heterotic effects relative to midparent are presented in Table 4.

The most significant and desirable heterosis relative to mid-parent was exhibited by six crosses (P1xP2, P1xP5, P1xP8, P5xP6, P5xP8 and P5xP9) for earliness, eleven crosses (P1xP2, P1xP5, P1xP6, $\mathrm{P} 2 \times \mathrm{P} 3, \mathrm{P} 2 \mathrm{xP}, \mathrm{P} 2 \times \mathrm{P} 5, \mathrm{P} 2 \times \mathrm{P} 6, \mathrm{P} 3 \times \mathrm{P} 4, \mathrm{P} 3 \times \mathrm{P} 5, \mathrm{P} 4 \times \mathrm{P} 7$, P6xP9) for No. of spikes plant ${ }^{-1}$, two crosses (P1xP10 and $\mathrm{P} 3 \times \mathrm{P} 10)$ for No. of grains spike ${ }^{-1}$, ten crosses (P1xP6, P3xP4, P3xP9, P4xP5, P4xP8, P4xP9, $\mathrm{P} 5 \times \mathrm{P} 7, \mathrm{P} 6 \times \mathrm{P} 7, \mathrm{P} 7 \mathrm{xP} 9$ and $\mathrm{P} 9 \times \mathrm{P} 10)$ for no of grain spike $^{-1}$, twelve crosses (P1xP5, P1xP6, P1xP8, P2xP5, P2xP6, P2xP7, P3xP5, P3xP7, P3xP10, P5xP9, $\mathrm{P} 6 \mathrm{xP7}$, P7xP9) for 1000-grain weight, Concerning grain yield plant ${ }^{-1}$, the nineteen crosses $(\mathrm{P} 1 \times \mathrm{P} 2$, P1xP8, P1xP8, P2xP4, P2xP6, P2xP7, P2xP9, P3xP7, $\mathrm{P} 3 \mathrm{PP}, \mathrm{P} 3 \mathrm{xP} 9, \mathrm{P} 4 \times \mathrm{P} 9, \mathrm{P} 5 \mathrm{xP} 8, \mathrm{P} 6 \mathrm{xP} 8, \mathrm{P} 6 \mathrm{xP}$, $\mathrm{P} 6 \mathrm{xP} 10, \mathrm{P} 7 \mathrm{xP} 8, \mathrm{P} 7 \mathrm{xP} 9, \mathrm{P} 8 \mathrm{xP} 9$ and $\mathrm{P} 9 \mathrm{xP} 10)$ showed significant positive heterotic effects. These hybrids exhibited heterosis for one or more of the contributing traits. Significant positive heterotic effects relative to higher yielding parent were obtained by Fonseca and Patterson (1968), Prasad et al (1998) and Abdullah et al (2002).

Table 4. Heterosis percentage relative to Mid-parent for studied traits in the studied $\mathrm{F}_{1}$ wheat crosses.

\begin{tabular}{|c|c|c|c|c|c|c|}
\hline \multirow{2}{*}{ Genotype } & days to heading & No. of spikes & No of spikelets & No of kernel & 1000-grain & Grain yield \\
\hline & Day & plant $^{-1}$ & spike-1 & spike-1 & weight (g) & plant $^{-1}(\mathrm{~g})$ \\
\hline $\mathrm{P} 1 \mathrm{xP} 2$ & $-4.19 *$ & $21.00 * *$ & -4.44 & -4.80 & $-6.44 *$ & $5.28 *$ \\
\hline P1xP3 & -2.27 & $-36.23 * *$ & 0.89 & $-9.87 *$ & 3.07 & $-21.07 * *$ \\
\hline $\mathrm{P} 1 \times \mathrm{P} 4$ & 0.50 & 5.27 & -4.73 & -2.43 & $-23.96 * *$ & $8.33 *$ \\
\hline P1xP5 & $-4.68 *$ & $19.79 * *$ & 0.90 & -2.80 & $5.24 *$ & $-20.35 * *$ \\
\hline P1xP6 & $5.59 * *$ & $25.80 * *$ & -3.88 & $17.42 * *$ & $10.04 * *$ & 0.23 \\
\hline P1xP7 & $7.28 * *$ & $-27.32 * *$ & 1.97 & $-5.50 *$ & $-11.05^{* *}$ & $-5.02 *$ \\
\hline $\mathrm{P} 1 \mathrm{xP} 8$ & $-4.15^{*}$ & -1.72 & -3.40 & 0.48 & $5.51 *$ & $14.91 * *$ \\
\hline P1xP9 & $6.12 * *$ & $-13.51 * *$ & $-11.63^{* *}$ & 1.00 & $-5.93 *$ & $-14.07 * *$ \\
\hline P1xP10 & 3.59 & $-12.32 * *$ & $39.91 * *$ & 1.07 & $-5.03 *$ & -2.97 \\
\hline $\mathrm{P} 2 \mathrm{xP} 3$ & -3.76 & $27.15^{* *}$ & $-11.69 * *$ & $-15.36 * *$ & 0.45 & -4.97 \\
\hline $\mathrm{P} 2 \mathrm{xP} 4$ & -2.40 & $26.92 * *$ & 4.31 & $-10.32 * *$ & -0.12 & $12.35 * *$ \\
\hline $\mathrm{P} 2 \mathrm{xP5}$ & 2.03 & $26.09 * *$ & 3.75 & $-10.51 * *$ & $15.13 * *$ & $-17.93 * *$ \\
\hline $\mathrm{P} 2 \mathrm{xP6}$ & 0.00 & $31.36 * *$ & -2.80 & $-15.44 * *$ & $20.81 * *$ & $12.46^{* *}$ \\
\hline P2xP7 & $4.73 * *$ & $-10.04 * *$ & 3.62 & $-11.03 * *$ & $7.53 *$ & $21.54 * *$ \\
\hline $\mathrm{P} 2 \mathrm{xP} 8$ & -3.68 & $-9.39 * *$ & 2.00 & $-15.05 * *$ & 4.46 & 4.04 \\
\hline $\mathrm{P} 2 \mathrm{xP9}$ & 2.07 & $-39.69 * *$ & -4.89 & -5.14 & 3.06 & $19.59 * *$ \\
\hline P2xP10 & 0.00 & $-14.01 * *$ & $-13.48 * *$ & -4.06 & -1.70 & -1.10 \\
\hline $\mathrm{P} 3 \mathrm{xP} 4$ & -0.81 & $25.27 * *$ & 0.57 & $19.43 * *$ & $-22.46 * *$ & $-13.07 * *$ \\
\hline $\mathrm{P} 3 \times \mathrm{P} 5$ & 0.47 & $37.74 * *$ & $-7.87 *$ & 2.81 & $23.49 * *$ & $-13.64 * *$ \\
\hline
\end{tabular}




\begin{tabular}{|c|c|c|c|c|c|c|}
\hline P3xP6 & 2.56 & $-7.19 *$ & 1.45 & $-10.63 * *$ & 2.40 & $5.29 *$ \\
\hline P3xP7 & 1.15 & $-25.78 * *$ & -0.44 & -2.95 & $11.20 * *$ & $15.10 * *$ \\
\hline P3xP8 & -1.77 & $-41.71 * *$ & -8.75 & $-17.84 * *$ & 7.41 & $16.51 * *$ \\
\hline P3xP9 & 2.73 & $-11.37 * *$ & -9.16 & $8.18^{*}$ & $-8.36^{*}$ & $13.75 * *$ \\
\hline $\mathrm{P} 3 \times \mathrm{P} 10$ & -0.95 & $-9.42 * *$ & $10.61 * *$ & -0.35 & $17.40 * *$ & -1.97 \\
\hline $\mathrm{P} 4 \mathrm{xP5}$ & 0.96 & $-45.84 * *$ & 0.87 & $5.11 *$ & -2.79 & $-6.85 *$ \\
\hline P4xP6 & 2.77 & $-29.79 * *$ & -1.74 & 1.42 & $-9.69 * *$ & $-13.14 * *$ \\
\hline $\mathrm{P} 4 \mathrm{xP7}$ & $10.74 * *$ & $55.37 * *$ & -5.43 & -4.06 & $-17.29 * *$ & $-23.82 * *$ \\
\hline P4xP8 & $11.51 * *$ & $-18.80 * *$ & 3.59 & $12.61 * *$ & $-25.92 * *$ & $-23.00 * *$ \\
\hline $\mathrm{P} 4 \times \mathrm{P} 9$ & 3.93 & $-11.23^{* *}$ & $-12.67 * *$ & $11.79 * *$ & 2.45 & $7.65^{*}$ \\
\hline P4xP10 & -1.13 & $-33.02 * *$ & -4.93 & 2.68 & $-11.57 * *$ & $-10.25^{* *}$ \\
\hline P5xP6 & $-6.20 * *$ & $-28.18 * *$ & $-15.29 * *$ & -4.43 & $9.08 * *$ & -0.23 \\
\hline $\mathrm{P} 5 \times \mathrm{XP7}$ & 3.59 & 1.07 & -0.75 & $9.57 *$ & $-12.70 * *$ & 2.50 \\
\hline P5xP8 & $-6.09 * *$ & -2.62 & -9.75 & $-19.63 * *$ & -0.39 & $5.62 *$ \\
\hline P5xP9 & $-5.11 * *$ & $-35.40 * *$ & $-14.21 * *$ & -0.99 & $8.94 *$ & $-11.16^{* *}$ \\
\hline $\mathrm{P} 5 \times \mathrm{P} 10$ & 1.42 & $-6.11 *$ & -4.10 & -3.08 & 4.10 & 3.69 \\
\hline P6xP7 & 2.83 & $-18.42 * *$ & 2.52 & $5.59 *$ & $11.49 * *$ & -0.22 \\
\hline P6xP8 & $4.73 *$ & $-28.65 * *$ & -1.01 & -1.50 & $-5.17 *$ & $17.65 * *$ \\
\hline P6xP9 & 3.74 & $13.89 * *$ & $-7.88^{*}$ & -2.17 & $-13.74 * *$ & $27.87 * *$ \\
\hline P6xP10 & 1.93 & $-30.58 * *$ & -2.87 & $-11.40^{* *}$ & $-17.10^{* *}$ & $20.72 * *$ \\
\hline P7xP8 & $5.03 * *$ & $-39.40 * *$ & 5.87 & -1.59 & $-11.50 * *$ & $36.82^{* *}$ \\
\hline P7xP9 & $9.03 * *$ & $-15.83 *$ & -5.36 & $10.29 * *$ & $12.24 * *$ & $24.40 * *$ \\
\hline P7xP10 & -0.50 & $-24.58 * *$ & -4.89 & $-11.93 * *$ & $-14.43 * *$ & -2.79 \\
\hline P8xP9 & $4.92 *$ & $-44.55 * *$ & $-7.40^{*}$ & $-14.00 * *$ & -4.72 & $5.96^{*}$ \\
\hline P8xP10 & -1.13 & $-29.92 * *$ & -1.19 & $-26.11 * *$ & -2.74 & $-9.25 * *$ \\
\hline P9xP10 & 3.39 & $-13.92 * *$ & -4.62 & $5.98^{*}$ & $-6.91 * *$ & $7.82 *$ \\
\hline
\end{tabular}

$* \mathbf{p}<0.05 ; * * \mathbf{p}<0.01$

\section{Combining ability}

The analysis of variance for both general (GCA) and specific (SCA) combining abilities show that the mean squares were highly significant for all studied traits in both generations (Table 2) which indicates the importance of both additive and non-additive gene effects in the inheritance of such traits.

The relative importance of additive and nonadditive gene action is essential for the development of an efficient hybridization program. The concept of combining ability as a measure of gene action refers to the capacity or ability of genotype to transmit superior performance to its crosses. The value of an inbred line depends on its ability to produce superior hybrids in combination with other inbreds. If both GCA and SCA mean squares are significant, it is vital to determine the type of gene action which is important in determining the performance of progeny. To overcome such situation the magnitude of mean squares can be used to assume the relative importance of general and specific combining ability mean squares which were highly significant. Hence, GCA/ SCA ratio was used to reveal the nature of genetic variance involved. The ratio of MS GCA/ MS SCA (Table 2) displays the relative importance of additive and additive by additive gene action effects in their inheritance for all studied traits except, days to heading and No of spike plant ${ }^{-1}$. Therefore, selection for these traits in early generations would be effective in developing the high yielding varieties in wheat breeding programs. The genetic variance was previously reported to be mostly due to additive for yield traits by El Seidy and Hamada (1997). On the other hand, the non-additive genetic variance was previously reported to be the most prevalent for plant height by Abd El-Aty and Katta (2002); No. of spike plant $^{-1}$ and No. of kernels spike ${ }^{-1}$ by Abd El-Aty and Katta (2002); for 1000-grain weight by Abd El-Aty and Katta (2002); For grain yield plant ${ }^{-1}$ by Siddique et al. (2004), El-Hosary and Nour El Deen (2015) and El-Hosary et al. (2019a).

\section{General combining ability effects}

General combining ability effects $\hat{g}_{i}$ of individual parent for each trait from both $F_{1}$ generation is presented in Table 5. High positive response would be of interest for all studied traits except for days to heading since early genotype is preferred due to early maturity, escape for disease which detected at the end of season and early harvest. Therefore, negative combining ability effects regarding days to heading are preferred in wheat. 
Table 5. Estimates of parental general combining ability effects for all studied traits in $\mathrm{F}_{1}$ diallel crosses.

\begin{tabular}{|c|c|c|c|c|c|c|}
\hline \multirow[t]{2}{*}{ Parent } & \multirow{2}{*}{$\begin{array}{l}\text { days to } \\
\text { heading }\end{array}$} & $\begin{array}{l}\text { No. of } \\
\text { spikes }\end{array}$ & $\begin{array}{l}\text { No. of } \\
\text { grains }\end{array}$ & \multirow{2}{*}{$\begin{array}{l}\text { No of grain } \\
\text { spike }^{-1}\end{array}$} & \multirow{2}{*}{$\begin{array}{r}\begin{array}{r}\text { 1000- } \\
\text { grain }\end{array} \\
\text { weight } \\
\end{array}$} & \multirow{2}{*}{$\begin{array}{c}\begin{array}{c}\text { Grain } \\
\text { yield }\end{array} \\
\text { plant }^{-1}\end{array}$} \\
\hline & & plant $^{-1}$ & spike $^{-1}$ & & & \\
\hline Abu-Graib (P1) & $-1.96 * *$ & $-2.20 * *$ & 0.28 & $-2.32 * *$ & $-1.00 * *$ & $0.79 * *$ \\
\hline $\operatorname{Kawz}(\mathbf{P 2})$ & 0.62 & -0.45 & $-1.27 * *$ & $2.08 * *$ & $1.77 * *$ & 0.32 \\
\hline Osais (P3) & 0.18 & $1.68 * *$ & 0.22 & 0.04 & 0.33 & $0.49 *$ \\
\hline Site mall(P4) & 0.43 & 0.13 & 0.29 & $1.26 * *$ & -0.11 & $-2.11 * *$ \\
\hline Florka(P5) & -0.27 & $-0.68^{*}$ & $-0.55 * *$ & $1.12 * *$ & $1.33 * *$ & $1.31 * *$ \\
\hline Kalak (P6) & 0.59 & -0.49 & -0.11 & $-2.12 * *$ & -0.22 & 0.23 \\
\hline Millan(P7) & -0.10 & 0.06 & 0.13 & $0.86^{*}$ & $-2.30 * *$ & $-3.10 * *$ \\
\hline Hithab(P8) & $-0.99 * *$ & $-1.23 * *$ & $0.33 * *$ & $-1.41 * *$ & 0.17 & 0.40 \\
\hline Ibaa 99(P9) & $1.18 * *$ & $2.85 * *$ & $0.64 * *$ & 0.41 & -0.40 & $2.69 * *$ \\
\hline Sham 6 (P10) & 0.32 & 0.32 & 0.05 & 0.07 & 0.42 & $-1.01 * *$ \\
\hline LSD gi $5 \%$ & 0.69 & 0.68 & 0.31 & 0.66 & 0.55 & 0.46 \\
\hline LSD gi $1 \%$ & 0.90 & 0.89 & 0.41 & 0.87 & 0.73 & 0.61 \\
\hline LSD gi-gj 5\% & 1.02 & 1.01 & 0.47 & 0.98 & 0.82 & 0.69 \\
\hline LSD gi-gj $1 \%$ & 1.34 & 1.32 & 0.62 & 1.29 & 1.08 & 0.91 \\
\hline
\end{tabular}

The parental variety P1 (Abu-Graib) exhibited significant desirable $\hat{g}_{i}$ effect among all the tested parents for days to heading and grain yield plant ${ }^{-1}$ in $\mathrm{F}_{1}$. Thus it could be utilized to reduce days to maturity in wheat. The parental variety $\mathrm{P}_{2}$ (Kawz) gave significant positive $\hat{g}_{i}$ effects for No of grain spike ${ }^{-1}$ and the 1000 kernel weight in the $F_{1}$ generation. But, it gave significant undesirable or insignificant $\hat{g}_{i}$ effects for other traits. The variety $\mathrm{P}_{3}$ (Osais) expressed significant negative $\hat{g}_{i}$ effects and seemed to be the best combiner for No. of spikes plant ${ }^{-1}$ and grain yield plant ${ }^{1}$. The parental variety $\mathrm{P}_{4}$ (Site mall) expressed significant positive $\hat{g}_{i}$ effects for No of grain spike ${ }^{-1}$. The parental variety $\mathrm{P}_{5}$ (Florka) expressed significant desirable $\hat{g}_{i}$ effects for No of grain spike-1, 1000kernel weight and grain yield plant ${ }^{-1}$ in $\mathrm{F}_{1}$ generation.

The parental line $\mathrm{P}_{7}$ (Millan) expressed significant positive $\hat{g}_{i}$ effects for No of grain spike ${ }^{-1}$ in the $F_{1}$. The parental variety $\mathrm{P}_{8}$ (Hithab) gave significant positive $\hat{g}_{i}$ effects for No. of spikes plant ${ }^{-1}$, and significant negative effects for days to heading. But, it gave significant undesirable or insignificant $\hat{g}_{i}$ effects for other traits. The parental variety $\mathrm{P}_{9}$ (Ibaa 99) gave significant positive $\hat{g}_{i}$ effects for No. of spikes plant ${ }^{-1}$, No. of grains spike $\mathrm{e}^{-1}$ and grain yield plant ${ }^{-1}$. However, it gave significant undesirable or insignificant $\hat{g}_{i}$ effects for other traits. Such obtained results suggested that a great opportunity for selection would be possible for yield and its components having earliness. These results are in harmony with those obtained by Hasnain et al (2006), Seleem (2006), Gurmani et al (2007), ELShaarawy and Koumber (2010), Seleem and Koumber (2011) EL Saadoown (2017).

\section{Specific combining ability effects}

Specific combining ability effects $S_{i j}$ of both $F_{1}$ for all traits are presented in Table 6 . As for days to heading the crosses of: $\mathrm{P} 1 \times \mathrm{P} 2, \mathrm{P}_{1} \mathrm{PP}_{5}, \mathrm{P} 1 \times \mathrm{PP} 8, \mathrm{P} 2 \mathrm{xP} 3$,
$\mathrm{P} 2 \times \mathrm{P} 4, \mathrm{P} 2 \mathrm{xP} 8, \mathrm{P} 4 \times \mathrm{P} 10, \mathrm{P} 5 \mathrm{xP} 6, \mathrm{P} 5 \mathrm{xP} 8, \mathrm{P} 5 \mathrm{xP} 9$ and P7xP10 gave significant and negative $S_{i j}$ effects. With regard to No. of spikes plant ${ }^{-1}$, eleven crosses expressed significant and positive $S_{i j}$ effects at $\mathrm{F}_{1}$ generation. Such results indicate that crosses P3xP5, $\mathrm{P} 4 \times \mathrm{PP} 7$ and $\mathrm{P} 6 \mathrm{xP} 9$ of $\mathrm{F}_{1}$ recorded the highest desirable $S_{i j}$ effects. The other crosses had either significant negative or insignificant $S_{i j}$ effects for this trait. As for No of grains spike ${ }^{-1}$ seven crosses $\left(\mathrm{P}_{1} \mathrm{xP}_{10}, \mathrm{P}_{2} \mathrm{XP}_{4}\right.$, $\mathrm{P}_{2} \mathrm{XP}_{5}, \mathrm{P}_{3} \times \mathrm{P}_{10}, \mathrm{P}_{4} \times \mathrm{P}_{5} \mathrm{P}_{4} \times \mathrm{P}_{8}$ and $\mathrm{P}_{7} \times \mathrm{P}_{8}$ gave significant and positive ${ }^{\wedge} S_{i j}$ effects. The other hybrids gave undesirable $S_{i j}$ effects for this trait.For No of kernel spike $^{-1}$ and 1000-grain weight, thirteen crosses for each trait had significant positive $S_{i j}$ effects. Interand intera-allelic interactions were detected in the crosses P1xP6, P1xP7, P3xP5, P4xP9, P6xP7 and $\mathrm{P} 7 \mathrm{xP} 9$ in both traits.

For grain yield phant $^{-1}$, nineteen crosses had significant and positive $S_{i j}$ effects in $\mathrm{F}_{1}$ generation. The crosses $\mathrm{P} 1 \mathrm{xP} 3$ and $\mathrm{P} 7 \mathrm{xP} 8$ gave the highest desirable $S_{i j}$ effects.

If crosses of high SCA involve both parental lines which also are good combiners, they could be exploited for breeding varieties. Nevertheless, if crosses of high SCA involve only one good combiner, such combinations would throw out desirable transgressive segregates provided that the additive genetic system in the good combiner (as well as complementary and epistatic effects in the crosses) act in the same direction to reduce undesirable characteristics and maximize the character under consideration. The correlation coefficient between mean performance of crosses and their $S_{i j}$ effects was positive and significant. Therefore, the mean performance of crosses could be a reliable and effective indication for their specific combining ability effects for all studied traits. 
Table 6. Estimates of specific combining ability effects of the parental combination for all studied traits in $F_{1}$ diallel crosses.

\begin{tabular}{|c|c|c|c|c|c|c|}
\hline Cross & $\begin{array}{c}\text { days to } \\
\text { heading }\end{array}$ & $\begin{array}{c}\text { No of spike } \\
\text { plant }^{-1}\end{array}$ & $\begin{array}{c}\text { No of spikelets } \\
\text { spike }^{-1}\end{array}$ & $\begin{array}{c}\text { No of kernel } \\
\text { spike }^{-1}\end{array}$ & $\begin{array}{c}\text { 1000-grain } \\
\text { weight }\end{array}$ & $\begin{array}{c}\text { Grain yield } \\
\text { plant }^{-1}\end{array}$ \\
\hline P1xP2 & $-3.59 * *$ & 2.10 & $-1.16^{*}$ & 0.87 & $-3.19 * *$ & $2.46 * *$ \\
\hline P1xP3 & -1.81 & $-8.92 * *$ & 0.03 & $-4.23 * *$ & 0.68 & $-7.24 * *$ \\
\hline P1xP4 & -1.39 & 0.52 & $-1.31 *$ & $-3.32 * *$ & $-5.41 * *$ & $7.37 * *$ \\
\hline P1xP5 & $-3.37 * *$ & $3.88 * *$ & 0.46 & -1.07 & 0.95 & $-5.56 * *$ \\
\hline P1xP6 & $4.44 * *$ & $6.25 * *$ & -0.91 & $7.84 * *$ & $4.06^{* *}$ & -0.39 \\
\hline P1xP7 & $3.80 * *$ & $-5.31 * *$ & -0.15 & $-2.83^{*}$ & $-2.56 * *$ & $-2.16^{* *}$ \\
\hline P1xP8 & $-4.64 * *$ & 3.77 & -1.02 & $3.01 * *$ & $3.81 * *$ & $5.84 * *$ \\
\hline P1xP9 & $3.86^{* *}$ & -0.65 & $-1.87 * *$ & -0.91 & -1.22 & $-6.94 * *$ \\
\hline P1xP10 & $3.38 * *$ & -0.23 & $7.73^{* *}$ & 1.73 & -0.14 & 0.39 \\
\hline P2xP3 & $-2.39 *$ & $5.09 * *$ & $-2.03 * *$ & $-4.17 * *$ & $-2.56 * *$ & $-2.83 * *$ \\
\hline P2xP4 & $-3.31 * *$ & $3.98 * *$ & $1.36^{*}$ & $-3.85 * *$ & $2.02 *$ & $5.81 * *$ \\
\hline P2xP5 & $4.72 * *$ & $3.90 * *$ & $1.73 * *$ & -1.71 & $2.38 *$ & $-6.70 * *$ \\
\hline P2xP6 & -0.14 & $6.18 * *$ & 0.03 & $-4.05 * *$ & $5.83 * *$ & 1.37 \\
\hline P2xP7 & $2.55 *$ & $-2.62 *$ & 0.86 & $-2.45^{*}$ & 1.81 & $4.42 * *$ \\
\hline P2xP8 & $-3.23 * *$ & 0.35 & 0.86 & -1.72 & 1.14 & $-1.72 *$ \\
\hline P2xP9 & 0.94 & $-9.74 * *$ & 0.48 & -0.23 & -0.16 & $4.18 * *$ \\
\hline P2xP10 & 0.80 & -2.14 & $-3.03 * *$ & 2.85 & -1.14 & $-1.67 *$ \\
\hline P3xP4 & -1.87 & $6.63 * *$ & 0.62 & $8.07 * *$ & $-6.61 * *$ & $-2.76 * *$ \\
\hline P3xP5 & $2.83^{*}$ & $9.99 * *$ & -0.82 & $2.58 *$ & $5.59 * *$ & $-3.25 * *$ \\
\hline P3xP6 & 2.30 & -0.97 & 1.02 & $-3.98 * *$ & -0.70 & 0.60 \\
\hline P3xP7 & -1.34 & $-5.52 * *$ & 0.04 & -0.85 & $3.35^{* *}$ & $4.33^{* *}$ \\
\hline P3xP8 & -1.45 & $-7.79 * *$ & $-1.56 * *$ & $-5.37 * *$ & $2.54 * *$ & $5.25 * *$ \\
\hline P3xP9 & 1.38 & 0.02 & -0.61 & $3.49 * *$ & $-4.02 * *$ & $3.97 * *$ \\
\hline P3xP10 & -0.42 & 0.66 & $2.19 * *$ & 1.94 & $6.50 * *$ & -0.19 \\
\hline P4xP5 & 0.91 & $-11.34 * *$ & $1.11^{*}$ & 1.09 & 0.73 & $1.59 *$ \\
\hline P4xP6 & 0.05 & $-6.97 * *$ & 0.21 & -0.88 & -0.69 & $-4.99 * *$ \\
\hline P4xP7 & $5.74 * *$ & $15.91 * *$ & $-1.16^{*}$ & $-3.93 * *$ & $-2.58 * *$ & $-8.18 * *$ \\
\hline P4xP8 & $9.63 * *$ & -1.01 & $1.24 *$ & $7.31 * *$ & $-6.39 * *$ & $-8.81 * *$ \\
\hline P4xP9 & 0.13 & -0.20 & $-1.54 * *$ & $2.49 *$ & $4.82^{* *}$ & $2.99 * *$ \\
\hline P4xP10 & $-3.01 *$ & $-6.34 * *$ & $-1.35^{*}$ & 0.85 & -0.26 & $-1.81^{*}$ \\
\hline P5xP6 & $-5.92 * *$ & $-6.17 * *$ & $-2.36 * *$ & -1.19 & 1.20 & 0.31 \\
\hline P5xP7 & 2.11 & 1.83 & 0.41 & $5.40 * *$ & $-5.62 * *$ & $1.66^{*}$ \\
\hline P5xP8 & $-5.01 * *$ & $3.80 * *$ & $-1.33^{*}$ & $-6.56 * *$ & -0.96 & $2.93 * *$ \\
\hline P5xP9 & $-5.84 * *$ & $-7.29 * *$ & $-1.38 *$ & -1.06 & 1.78 & $-4.93 * *$ \\
\hline P5xP10 & $3.02 *$ & 1.58 & -0.65 & 0.43 & 0.90 & $4.16^{* *}$ \\
\hline P6xP7 & -1.42 & $-2.57 *$ & 0.84 & $3.08 * *$ & $4.30 * *$ & $-3.91 * *$ \\
\hline P6xP8 & $3.47 * *$ & $-2.83 *$ & 0.37 & $2.75^{*}$ & -1.41 & $2.64 * *$ \\
\hline P6xP9 & 0.63 & $8.75^{* *}$ & -0.14 & -1.67 & $-5.21 * *$ & $6.57 * *$ \\
\hline P6xP10 & 0.83 & $-4.72 * *$ & -0.69 & $-3.59 * *$ & $-5.88 * *$ & $5.96 * *$ \\
\hline P7xP8 & 1.49 & $-5.61 * *$ & $1.40 * *$ & $2.25 *$ & $-2.69 * *$ & $8.96 * *$ \\
\hline P7xP9 & $3.66 * *$ & -0.03 & -0.05 & $3.90 * *$ & $5.21 * *$ & $4.70 * *$ \\
\hline P7xP10 & $-3.81 * *$ & $-2.50 *$ & $-1.66 * *$ & $-4.57 * *$ & $-3.70 * *$ & $-2.68 * *$ \\
\hline P8xP9 & $2.55^{*}$ & $-7.29 * *$ & -0.25 & $-4.95 * *$ & -0.66 & $-1.94 *$ \\
\hline P8xP10 & -1.59 & -1.65 & -0.52 & $-8.93 * *$ & 0.89 & $-5.40 * *$ \\
\hline P9xP10 & 1.24 & 2.05 & -0.17 & $3.34 * *$ & -1.41 & 0.87 \\
\hline LSD5\%(sij) & 2.31 & 2.27 & 1.06 & 2.22 & 1.86 & 1.56 \\
\hline LSD1\%(sij) & 3.03 & 2.99 & 1.39 & 2.91 & 2.44 & 2.05 \\
\hline LSD5\%(sij-sik) & 3.39 & 3.34 & 1.55 & 3.26 & 2.73 & 2.29 \\
\hline LSD1\%(sij-sik) & 4.46 & 4.39 & 2.04 & 4.28 & 3.59 & 3.01 \\
\hline LSD5\% (sij-ski) & 3.23 & 3.19 & 1.48 & 3.11 & 2.60 & 2.18 \\
\hline LSD1\%(sij-ski) & 4.25 & 4.19 & 1.95 & 4.08 & 3.42 & 2.87 \\
\hline
\end{tabular}

$* \mathbf{p}<0.05 ; * * \mathbf{p}<0.01$. 
References

Abd El-Aty, M.A. and Y. S. Katta (2002). Genetic analysis and heterosis of grain yield and related traits in bread wheat (Triticum aestivum L.). J. Agric. Res. Tanta Univ., 28 (2): 287-300.

Abdullah, G.M., A.S. Khan and Z. Ali (2002). Heterosis study of certain important traits in wheat. Int. J. Agri. Biol. 4:326-328.

Allah, S.U., A.S. Khan, A. Raza and S. Sadique (2010). Gene action analysis of yield and yield related traits in spring wheat (Triticum aestivum). Int. J. Agri. Biol. 12:125-128.

Arunachalam, V. (1976). Evaluation of diallel crosses by graphical and combining ability methods. Indian J. Genet. 36: 358-366.

Ashoush, H.A. (2006). Breeding for yield and its components in some bread wheat crosses (Triticum aestivum L.). Alex. J. of Agric Sci. 27 (3): 322-335.

Baker, R.J. (1978). Issues in diallel analysis. Crop Sci. 18: 533-536.

Bakhsh A., A. Hussain and A.S. Khan (2003). Genetic studies of plant height, yield and its components in bread wheat. Sarhad J. Agric. 19:529-534.

Bhatt, G.M. (1971). Heterosis performance and combining ability in a diallel cross among spring wheat. (Triticum aestivm L.). Ast. J. Agric. Res. 22:359-369.

El-Hosary A.A.; M. El. M. El-Badawy ; S.A.S Mehasen , A.A.A.; El-Hosary , T.A. ElAkkad and A. El-Fahdawy (2019 a). Genetic diversity among wheat genotypes using RAPD markers and its implication on genetic variability of diallel crosses. Bioscience Research, 16(2): 1258-1266.

El-Hosary A.A.A. and Gehan A. Nour El Deen (2015). Genetic analysis in the $F 1$ and $F 2$ wheat generations of diallel crosses. Egypt. J. Plant Breed. 19 (2): 355-373.

EL-Hosary A.A.A. , El Saeed M. El-Gedwy and M.A. Abdel Salam (2019b). Utilization of ISSR marker and tolerance indices for selecting adapted wheat genotypes under water stress. Bioscience Research 16(2):1611-1625.

EL Saadoown A.W., A.A. EL Hosary, S.A. Sedhom, M.EL.M. ELBadawy, A.A.A. El Hosary (2018). Determination of Combining Ability and Genetic Diversity Using ISSR Markers to Evaluate the Genetic Variability in Wheat. The 7th Scientific and 1st International Conference of Agricultural Researches, 10- 11 April 2018. 18: 67-80

EL Saadoown A.W., A.A. EL Hosary, S.A. Sedhom, M.EL.M. ELBadawy, A.A.A. El Hosary (2017). Genetic analysis of diallel crosses in wheat under stress and normal irrigation treatments. Egypt. J. Plant Breed. 21 ( 5 ): 279 292.
El-Seidy, E. H. and A. A. Hamada (1997). Genetic analysis of diallel crosses in wheat under normal irrigation and drainage water conditions. Annals of Agric. Sc., Moshtohor, 35 (4) : 1915-1932.

EL-Shaarawy, G.A. and R.M.A. Koumber (2010). Genetical studies on some agronomic characters in bread wheat crosses under low nitrogen fertilizer condition. J. Plant Prod., Mansoura Univ. 1(11): 1495-1519.

Ismail, R.M. (2002). Estimation of genetic parameters in the $F_{1}$ and $F_{2}$ generation of diallel crosses of bread wheat (Triticum aestivum L.). Bull. NRC, Egypt. 27(1) 85-106.

Farooq, J., I. Khaliq, A.S. Khan and M.A. Pervez (2010). Studing the genetic mechanism of some yield contributing traits in wheat. (Triticum aestivum). Int. J. Agri. Biol. 12:241-246.

Fonseca, S. and F.L. Patterson (1968). Hybrid vigour in seven parent diallel cross in common winter wheat (Triticium aestivum L.). Crop Sci. 8: 85-88.

Griffing, B. (1956). Concept of general and specific combining ability in relation to diallel crossing systems. Aus. J. of Biol. Sci. 9: 463-493.

Gurmani R., S.J. Khan, Z.A. Saqib, R. Khan, A. Shakeel and M. Ullah (2007). Genetic evaluation of some yield and yield related traits in wheat. Pak. J. Agric. Sci. 44:6-11.

Hasnain Z., G. Abbas, A. Saeed, A. Shakeel, A. Muhammad and M.A. Rahim (2006). Combining ability for plant height and yield related traits in wheat (Triticum aestivum L.). J. Agric. Res. 44:167-175.

Joshi, S.K., S. N. Sharma, D. L. Sinnghania and R. S. Sain (2004). Combining ability in the $F_{1}$ and $F_{2}$ generations of diallel cross in hexaploid wheat (Triticum aestivum L. Em. Thell). Hereditas.141:115-121.

Mather, K. and J.L. Jinks (1971). Biometrical Genetics. ( $2^{\text {nd }}$ ed.), Chapman and Hall Ltd. London.

Prasad, K.D., M.F. Haque and D.K. Ganguli (1998). Heterosis studies for yield and its components in bread wheat (Triticum aestivum L.). Indian J. Genet. 58: 97-100.

Seleem, S.A. (2006). Combining ability and type of gene action in common wheat. Minufiya J. Agric. Res. 31(2): 399-420.

Seleem, S.A. and R.M.A. Koumber (2011). Estimation of combining ability and gene action in the $F_{1}$ and $F_{2}$ generations in some breed wheat crosses. Minufiya J. Agric. Res. 36(6): 1627-1648.

Siddique, M., S. Ali , M. F. A. Malik and S. I. Awan (2004). Combining bility estimates for yield and yield components in spring wheat. Sarhad J. Agric. 20 (4): 48-63. 